\title{
The Effect of Organic and Inorganic Nutrient Sources on The Growth and Seed Yield of Bambara Nut (Vigna Subterranean (L) Verdc) Variety
}

\author{
Adeyeye $\mathrm{AS}^{1 *}$, Dimas $\mathrm{AE}^{1}$, Olalekan $\mathrm{KK}^{2}$, Lamidi $\mathrm{WA}^{2}$, Othman $\mathrm{HJ}^{1}$ and Ishaku $\mathrm{MA}^{1}$ \\ ${ }^{1}$ Department of Crop Production and Protection, Federal University Wukari, Nigeria \\ ${ }^{2}$ Department of Agronomy, Osun State University, Osogbo, Osun State Nigeria
}

*Corresponding author: Adeyeye AS, Department of Crop Production and

Protection, Federal University Wukari, Taraba, Nigeria.

Received Date: May 16, 2019

Published Date: May 29, 2019

Synopsis

The research was conducted at the Teaching and Research Farm, of Federal University Wukari, Taraba State Nigeria, during the raining seasons of 2016 and 2017 to assess the effects of organic and inorganic fertilizers on the growth and seed yield of Bambara nut varieties. The treatments consisted of two varieties of Bambara nuts, (white and black varieties) and the fertilizers: organic $\left(10,20 \mathrm{t} \mathrm{ha}^{-1}\right.$ of poultry manure), and inorganic (30 and $60 \mathrm{kgN} \mathrm{ha}^{-1}$ of Urea) with a control. These were laid out in a Randomized Complete Block Design (RCBD), with four replications. The data collected were on the growth and seed yield parameters of the crop and were analyzed using analysis of variance (ANOVA) and the differences among treatment means were separated using Duncan Multiple Range Test at 5\% level of probability. The results showed that $\mathrm{N}$ fertilizer application rate of $30 \mathrm{kgN} \mathrm{ha}^{-1}$ produced significant number of leaves, nodes, flowers, and plant height. Application of $20 \mathrm{t} \mathrm{ha}^{-1}$ poultry manure produced highest significant number of branches while urea application of $60 \mathrm{kgN} \mathrm{ha}^{-1}$ produced significantly highest pod weight. The control (without fertilizer) gave the significant highest weight of bad seeds while Poultry manure at $10 \mathrm{t} \mathrm{ha}^{-1}$ produced significant highest number of seeds, seed weight and number of pods. Therefore, application of $10 \mathrm{t}$ ha- 1 poultry manure and $30 \mathrm{kgN} / \mathrm{ha}$ urea are optimum to produce Bambara nut.

Keywords: Bambara nut; Poultry manure; Urea; Growth; Yield; Variety

\section{Introduction}

Bambara Groundnuts (Vignea subterranean), is an underutilized legume widely cultivated in Sub- Saharan Africa. Its center of origin is thought to be Bambara, near Timbuktu in Central Mali, West Africa hence its name Bambara Groundnut [1]. The crop has also been widely cultivated in tropical regions since the seventeenth century and was also domesticated in the semiarid zone of West Africa, probably around the headwaters of the Niger River, from where it spread in ancient times to Central Africa, and more recently to the Malagasy Republic [2]. It is the third most important crop after groundnuts and cowpeas, but it has low status as it is seen as a snack or food supplement but not a lucrative cash crop. It is an edible legume which serves as one of the main sources of income for small holder farmers. The seeds contain sufficient quantities of protein $(19 \%)$, carbohydrate $(63 \%)$, fat $(6.5 \%)$ and essential amino acids such as lysine, cysteine and methionine $[3,4]$. Thus, the crop produces a balanced food, high protein content and source of plant protein for human [5]. Crop production in Sub-
Saharan Africa is hindered by several factors such as drought, low soil fertility as well as restricted access to mineral fertilizers [1].

In Nigeria, farmers are always faced with the problem of soil fertility decline which has been considered as the most important biophysical constraints to crop yield and productivity [6]. Crop growth and yield development required mineral nutrition at appropriate amount and can be supplied to crop as fertilizer which is categorized as organic and inorganic. Integration of organic fertilizers such as poultry manure into the farming systems can therefore be a cheaper alternative to alleviating low soil fertility [6]. Poultry manure is a nutrient source for crop production [7-9], and has been shown to increase soil organic $\mathrm{C}$, total $\mathrm{N}$ and available $P$ [10]. When incorporated into soil promoted transformation and mineralization of less-labile inorganic and organic P into labile-P in the rhizosphere, which resulted in higher root $\mathrm{P}$ concentrations and higher total P uptake by plants [10]. The poultry manure could be a valuable fertilizer which serves as a suitable alternative to 
chemical fertilizer that is expensive for rural farmers in sub Saharan Africa. However, there seems to be little use of poultry manure and less knowledge available on their effects on crops especially Bambara nut for efficient utilization. As a legume crop, Bambara nut through its root system improved the soil fertility by nitrogen fixing bacteria present in their root nodules but this alone cannot satisfy the nitrogen requirement of the plant [11], hence there is a need for additional nitrogen supply to stimulate nodulation for optimum production [12]. Adequate supply of nitrogen has been found to be beneficial for carbohydrates and protein metabolism, promoting cell division and cell enlargement [13]. The judicious use of chemical fertilizer is also essential to maintain soil fertility [14]. Bambara nut usually grown with low input subsistence crop without fertilizer application in most of the farms and this made its production to be marginal. Hence more findings are needed to determine the fertilizer rate for optimum production under the savannah condition. Therefore, this study was undertaken to evaluate the effects of organic (poultry) and inorganic fertilizer (Urea) nutrient sources on the growth, and yield of two Bambara groundnut landraces grown in field conditions.

\section{Materials and Method}

\section{Site description}

The study was carried out at the Teaching and Research Farm of Federal University Wukari, Taraba State, Nigeria during the raining seasons of 2016 and 2017. Taraba state lies between latitude $6030,8030 \mathrm{~N}$ of the equator and longitude 90 and $120 \mathrm{E}$ of the Greenwich meridian with a land mass of $54.426 \mathrm{~km} 2$. The state has a tropical wet - dry climate, well drained alluvial soils and has both savannah and Rain forest vegetation. The rainfall ranges from $100 \mathrm{~mm}$ to $250 \mathrm{~mm}$ per annum in the north with the driest and wettest season lasting from December to February and July to September, respectively. Soil sample of the site was collected at $15 \mathrm{~cm}$ depth using an auger and poultry manure collected was taken for analysis while the land was ploughed and harrowed. The soil was analyzed for PH, nitrogen, carbon, organic matter and the concentration of phosphorus, calcium and magnesium. The soil PH was determined using the distilled water in KCL with a soil water ratio of 1:2.5. The suspense on was thoroughly stirred and allowed to stand for 30 minites after which the $\mathrm{PH}$ was determined using an electronic $\mathrm{PH}$ meter. Total nitrogen was determined by micro Kjeldahl digestion method described by A.O.A.C [15]. The cations ( $\mathrm{Ca}, \mathrm{Mg}$ ) were determined by the atomic absorption method as outlined in the Analysis of the official Analytical Chemists [15].

\section{Experimental treatments and design}

The experiment was a 2 x 5 factorial laid out in a randomized complete block design (RCBD) with four replications. There were ten (10) plots replicated four (4) times, which make up a total number of 40 plots for the experiments. The plot size of $2 \times 1 \mathrm{~m}$ was used with plant spacing of $50 \mathrm{~cm} \times 50 \mathrm{~cm}$. There was $1 \mathrm{~m}$ gap between plots and $2 \mathrm{~m}$ gap between replications. The treatments consisted of two organic fertilizers rate as 10 and 20t/ha (poultry manure) and two inorganic fertilizers rate 30 and $60 \mathrm{kgN} /$ ha (Urea) with a control $(0 \mathrm{kgN} / \mathrm{ha})$ and two varieties of Bambara nut (white and black varieties). The organic fertilizer (poultry manure) was applied on the plot two weeks before sowing, while the inorganic fertilizer (urea) was applied one week after seed emergence.

\section{Crop management}

The land was cleared manually using simple farm tools; cutlass, hoe and rake. The layout was then designed and pegged after which beds were raised using a hoe. On each bed, three (3) seeds were sown per hole and later thinned to one per stand after germination making a few 8 Stan per bed. The organic fertilizer (Poultry manure) was incorporated into the soil two weeks before sowing of seeds, while inorganic fertilizer (Urea) was applied to the plant one week after seed emergence. Weeding was done manually with the use of hoe to control weed. The field was weeded as when due throughout the experimentation.

\section{Data collection and analysis}

Data were collected on growth and yield parameters of the crop at various stages of plant growth starting from $2,4,6,8,10$, and 12 Weeks after planting. The parameters measured were: Plant height $(\mathrm{cm})$, Number of branches, nodes, leaves, flowers, and pods, weight of pods, weight of the seed shaft, Number of good seeds and bad seeds, weight of seeds. The data collected were subjected to statistical analysis of variance (ANOVA) at $\mathrm{P}=0.05$ as described by Gomez and Gomez [16] and significance difference among treatments means were evaluated using Duncan Multiple Range Test

\section{Results}

Soil analysis was conducted during the research and the results obtained showed that the soil had low nitrogen content, organic matter, organic carbon and ECEC, hence of low fertility status while the textural class of the soil is sandy loam (Table 1). Analysis of the poultry manure used for the research was also carried out as seen in (Table 2). The effects of Bambara nut variety on the growth parameters such as number of leaves, height of plant, number of nodes, and number of branches at different growing stages were presented in table 3.There was no significance difference in the number of leaves of Bambara nut at all growing stages measured, but white variety at 4 weeks after planting (WAP), had higher mean value for leaves number. Expectedly numbers of leaves increase as the plant age increase and reached the peak at 10WAP were the highest leaf number of 129.03 was produced by white variety, while the lowest number of leaves recorded was at week 4, for white variety (29.40a). The number of nodes was not different significantly among the two varieties, although in most cases white variety seems to have higher mean values except at 4WAP. The white variety had the highest number of nodes at 12WAP and the lowest node number at 4WAP (127.4a and 31.00a) respectively. The averages number of branches per plants at all growing stages shows a significant difference only at 4WAP where the black variety had the significant higher branches than white variety. The results obtained on plant height in the study, shows a significant difference at 6 and 12WAP and white variety had the significantly highest plant height respectively. The results obtained from the number of flowers taking among the two varieties showed no significant difference in the number of flowers (Figure 1). 


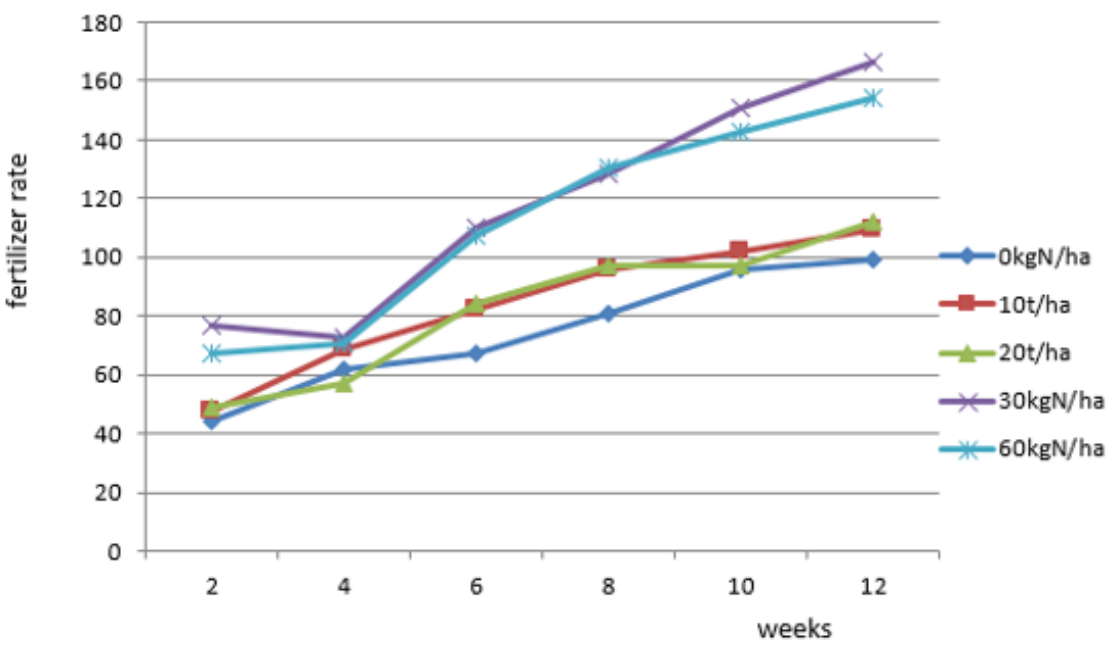

Figure 1: Effect of fertilizer application on Bambara nut number of levels at different growth.

Table 1: The soil chemical and physical analysis of the Teaching and Research Farm, Federal University, Wukari.

\begin{tabular}{|c|c|}
\hline $\mathbf{p H}$ & $\mathbf{5 . 7 5}$ \\
\hline Organic carbon (\%) & 1.36 \\
\hline Organic Matter (\%) & 2.35 \\
\hline Total N (\%) & 0.98 \\
\hline Available P (mg/kg) & 0.52 \\
\hline Exchangeable K (mol/kg -1) & 1.6 \\
\hline Exchangeable Na (mol/kg -1) & 2.1 \\
\hline Exchangeable Ca (mol/kg -1) & 3.8 \\
\hline Exchangeable Mg (mol/kg -1) & 1.8 \\
\hline Exchangeable Acidity (mol/kg -1) & 1.1 \\
\hline TEB & 9.3 \\
\hline CEC (c mol $/ \mathrm{kg}-1)$ & 10.4 \\
\hline Base Saturation (\%) & 89.4 \\
\hline Sand (g/kg) & 76.8 \\
\hline Clay (g/kg) & 15.2 \\
\hline Silt $(\mathrm{g} / \mathrm{kg})$ & 8 \\
\hline Textural Class & Sandy loam \\
\hline
\end{tabular}

Table 2: Analysis of poultry manure used in the experiment.

\begin{tabular}{|c|c|}
\hline Parameters & Values \\
\hline $\mathrm{pH}$ & 6.19 \\
\hline Nitrogen (\%) & 3.68 \\
\hline Phosphorus (\%) & 1.57 \\
\hline Organic Carbon (\%) & 8.29 \\
\hline Potassium (\%) & 0.81 \\
\hline Calcium (\%) & 2.62 \\
\hline Sodium (\%) & 0.07 \\
\hline Magnesium (\%) & 0.48 \\
\hline
\end{tabular}

The effects of fertilizer application on Bambara nut number of leaves are shown in (Figure 2). Application of fertilizer produced significant effects on the number of leaves at all growing stages sampled except at 2WAP. The plant that received $30 \mathrm{KgN} / \mathrm{ha} \mathrm{N}$ produced significantly higher number of leaves at $6,8,10$ and 12WAP while the control gave the least leaves number. While at two weeks after planting there was no significantly difference among the fertilizer treatments, but $30 \mathrm{KgN} /$ ha produced the highest mean value of leaves number when compared with other treatments (Table 3).

Table 3: Effect of variety on the growth parameters of Bambara nut at various stages of growth.

\begin{tabular}{|c|c|c|c|c|c|c|}
\hline Variety & Weeks & No. Of Leaves & No. Of Nodes & No. Of Branches & Plant Height & No. Of Flowers \\
\hline A & 2 & $57.35 \mathrm{a}$ & $16.39 \mathrm{a}$ & $9.81 \mathrm{a}$ & $7.64 \mathrm{a}$ & -- \\
\hline B & & $43.03 \mathrm{a}$ & $15.42 \mathrm{a}$ & $8.48 \mathrm{a}$ & $8.97 \mathrm{a}$ & -- \\
\hline A & 4 & $29.40 \mathrm{a}$ & $31.00 \mathrm{a}$ & $6.80 \mathrm{~b}$ & $17.33 \mathrm{a}$ & - \\
\hline B & & $31.15 \mathrm{a}$ & $32.52 \mathrm{a}$ & $7.50 \mathrm{a}$ & $18.13 \mathrm{a}$ & - \\
\hline A & 6 & $113.97 \mathrm{a}$ & $126.18 \mathrm{a}$ & $11.94 \mathrm{a}$ & $24.80 \mathrm{a}$ & $0.83 \mathrm{a}$ \\
\hline B & & $112.00 \mathrm{a}$ & $125.58 \mathrm{a}$ & $12.20 \mathrm{a}$ & $23.00 \mathrm{~b}$ & $0.64 \mathrm{a}$ \\
\hline A & 8 & $114.37 \mathrm{a}$ & $114.02 \mathrm{a}$ & $11.47 \mathrm{a}$ & $25.00 \mathrm{a}$ & $6.32 \mathrm{a}$ \\
\hline B & & $110.00 \mathrm{a}$ & $112.90 \mathrm{a}$ & $11.50 \mathrm{a}$ & $24.33 \mathrm{a}$ & $5.20 \mathrm{a}$ \\
\hline A & 10 & $129.03 \mathrm{a}$ & $126.38 \mathrm{a}$ & $12.80 \mathrm{a}$ & $24.50 \mathrm{a}$ & $0.98 \mathrm{a}$ \\
\hline B & & $125.28 \mathrm{a}$ & $122.83 \mathrm{a}$ & $11.50 \mathrm{a}$ & $23.84 \mathrm{a}$ & $1.08 \mathrm{a}$ \\
\hline A & 12 & $115.48 \mathrm{a}$ & $127.40 \mathrm{a}$ & $12.23 \mathrm{a}$ & $24.88 \mathrm{a}$ & $0.90 \mathrm{a}$ \\
\hline B & & $112.54 \mathrm{a}$ & $124.80 \mathrm{a}$ & $13.80 \mathrm{a}$ & $23.42 \mathrm{~b}$ & $0.62 \mathrm{a}$ \\
\hline
\end{tabular}

$A=$ White variety, $B=$ Black variety. Values with different letters along the columns are significantly different using DMRT at $5 \%$ probability level 


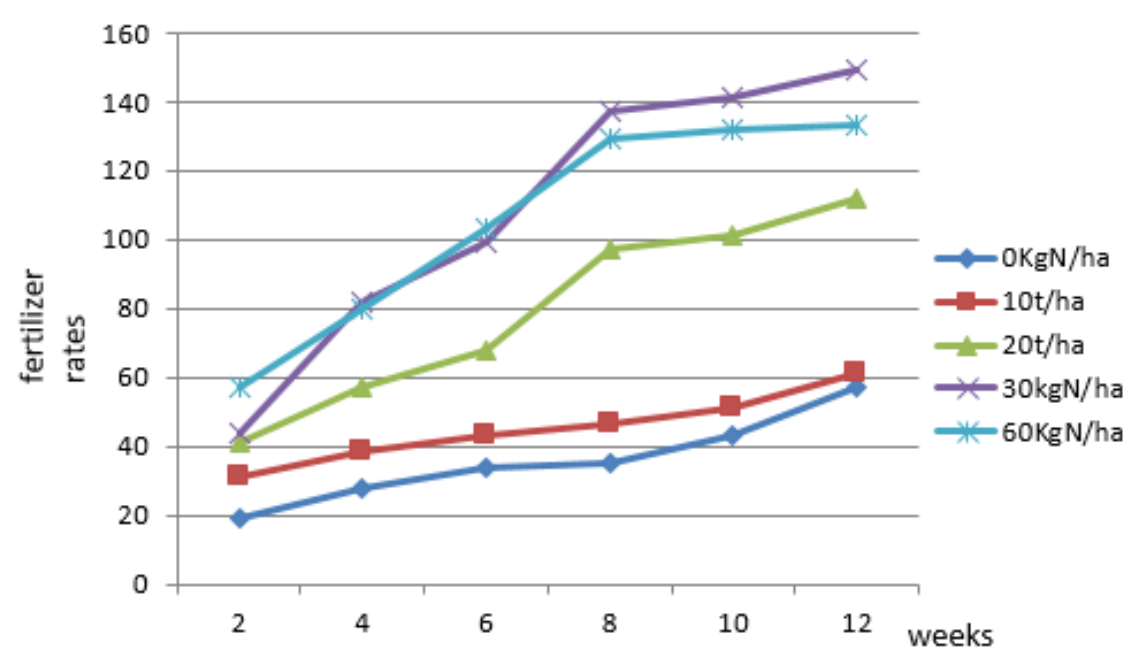

Figure 2: Effect of fertilizer application on Bambara nuts number of nodes.

The effect of fertilizer application on the number of nodes was significance at 4, 6, 8, 10 and 12WAP. Fertilizer treatment of $30 \mathrm{KgN}$ produced significantly higher number of nodes while the least nodes number came from the control $(0 \mathrm{kgN} / \mathrm{ha})$. Although there was no significant difference among the fertilizer treatments applied at 2 WAP, however plants that received $\mathrm{N}$ at $30 \mathrm{KgN} /$ ha gave higher node number. Application of fertilizers significantly affect the plant height of Bambara nut at 6, 8, 10 and 12WAP.In this case $60 \mathrm{KgN} /$ ha produced a significant higher plant height when compared with other fertilizer treatments in the study. Also, at $4 \mathrm{WAP}, 60 \mathrm{KgN} /$ ha produced the highest mean value for plant height despite no insignificant relationship among fertilizer treatments. (Figure 3). The number of branches of Bambara nuts was affected significantly by the fertilizer application at 4, 6, 8, and 10 WAP. Application of $\mathrm{N}$ at the rate of $60 \mathrm{kgN} /$ ha produced the significant higher number of branches at 6 and 10 WAP while at 4 and 8 WAP application of 10 and 20t/ha poultry manure gave the significant highest number of branches respectively (Figure 4). The effect of fertilizer application on Bambara nut number of flowers was significant only at 12 WAP. Application of $60 \mathrm{KgN} / \mathrm{haN}$ produced the significant highest number of flowers while the control $(0 \mathrm{KgN} / \mathrm{ha})$ gave the least (Figure 5). The results obtained from variety and fertilizer effects on Bambara nut number of leaves at different sampling period is sown in (Table 4) and the white variety of Bambara nut and $30 \mathrm{~kg} \mathrm{~N} / \mathrm{ha}$ N produced significantly highest number of leaves at all sampling periods taken and the least came from the control plant treatment. Variety and fertilizer treatments effect on Bambara nut number of nodes at different growth stages was significant at 2 and 4 WAP only. The white variety of Bambara nut and $30 \mathrm{kgN}$ N produced significantly highest number of nodes while at 4WAP the black variety and 10t/ ha poultry manure gave the highest nodes numbers (Table 5). The effects of variety and fertilizer treatments on Bambara nut plant height was also significant at 4, 6, and 12 WAP and at 4WAP black variety and $60 \mathrm{~kg} \mathrm{~N} / \mathrm{haN}$ fertilizer produced the tallest plants while at 6WAP it was the combination of white variety and $30 \mathrm{kgN} /$ ha fertilizer that gave the highest plant height. Furthermore, at $12 \mathrm{WAP}$ white variety and $60 \mathrm{kgN} / \mathrm{ha}$ and black variety and $60 \mathrm{kgN} /$ ha treatments produced the best height which was significantly different from other treatments combination in the study (Table $6,7)$. Bambara nut number of branches at different growth stages, was significant at 2, 4, 6, 8 and 10WAP and the results obtained showed that black variety and 10t/ha poultry manure at 2 and 4WAP had the significant higher number of branches per plant while at 6 and 10WAP the combination of black variety and $60 \mathrm{kgN} /$ ha $\mathrm{N}$ produced the significant highest branch number furthermore at 8WAP black variety with $20 \mathrm{t} /$ ha poultry manure had the best number of branches. The number of flowers at different growth stages showed that there was a significant difference except at $12 \mathrm{WA}$ where the white variety and $60 \mathrm{kgN} / \mathrm{ha} \mathrm{N}$ application gave the best result. (Table 9) showed the results obtained from the effects of variety of Bambara nut on seed yield parameters such as weight of pods, number of pods, weight of shaft, weight of seed, number of bad seeds, weight of bad seed. There was no significance difference among the varieties, but most often white variety have higher mean values on weight of pod, number of pods, weight of seeds, and weight of bad seed. Bambara nut seed yield parameters, was favored by the application of fertilizer in this study and there was no significance difference between the treatments although it was observed that application of poultry manure at the rate of $10 \mathrm{t} /$ ha gave the highest number of pods and seeds when compared to other treatments. The control plot gave the lowest number of seeds as compared to other treatments. (Table 10) showed the effects of variety and different fertilizer treatments on Bambara nut seed yield parameters at harvest. It was observed that there was no significant difference among the fertilizer treatments applied but pod weight had best mean value from the black variety and $60 \mathrm{kgN} /$ ha $\mathrm{N}$ fertilizer. Also, the number of pods was best when black variety and $10 \mathrm{t} /$ ha poultry manure was applied. The weight of shaft had the highest mean value when white variety of the nut combined with the control treatment. Also, the weight of seed was highest from combination of black variety and $60 \mathrm{kgN} /$ ha fertilizer treatment. Furthermore, the number of seed had a higher mean value when the two varieties of Bambara nut and 10t/ha poultry manure was combined respectively while the number of bad seed and weight of bad seed had the best mean values, when the control and white variety treatments were combined (Table 11). 


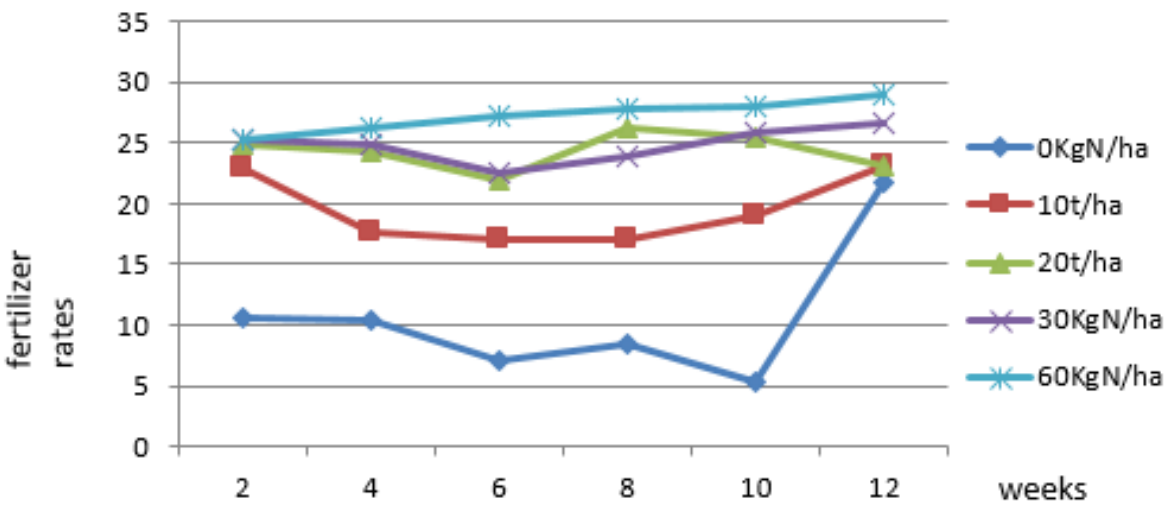

Figure 3: Effect of fertilizer application on Bambara nut plant height at different.

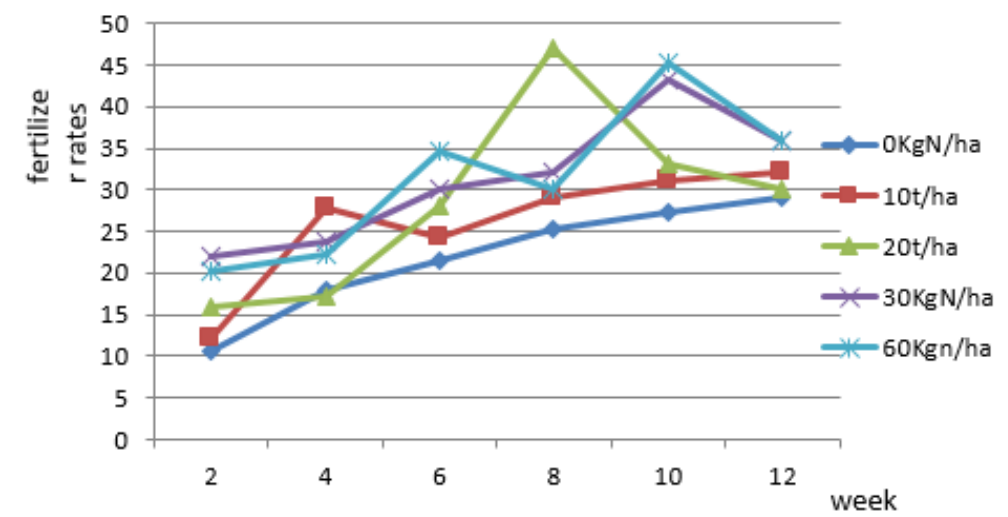

Figure 4

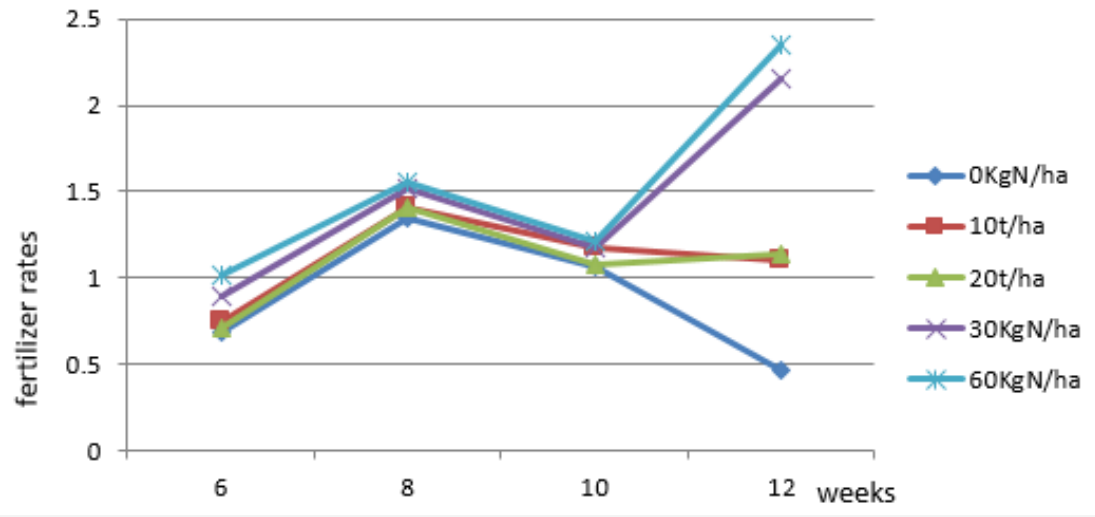

Figure 5: Effect of fertilizer application on the number of flowers at different growth.

Table 4: Effects of variety and fertilizer application on the Bambara nut number of leaves at different growth stages.

\begin{tabular}{|c|c|c|c|c|c|c|c|}
\hline Variety & Fertilizers & $\mathbf{2 w k}$ & $\mathbf{4 w k}$ & $\mathbf{6 w k}$ & $\mathbf{8 w k}$ & $\mathbf{1 0 w k}$ & $\mathbf{1 2 w k}$ \\
\hline $\mathrm{A}$ & $0 \mathrm{kgN} / \mathrm{ha}$ & $57.17 \mathrm{ab}$ & $28.17 \mathrm{a}$ & $124.58 \mathrm{ab}$ & $125.50 \mathrm{ab}$ & $134.92 \mathrm{abc}$ & $121.08 \mathrm{ab}$ \\
\hline $\mathrm{B}$ & $0 \mathrm{kgN} / \mathrm{ha}$ & $46.25 \mathrm{ab}$ & $30.67 \mathrm{a}$ & $112.67 \mathrm{ab}$ & $105.83 \mathrm{ab}$ & $119.58 \mathrm{abc}$ & $112.67 \mathrm{ab}$ \\
\hline $\mathrm{A}$ & $10 \mathrm{t} / \mathrm{ha}$ & $31.75 \mathrm{~b}$ & $35.42 \mathrm{a}$ & $107.50 \mathrm{ab}$ & $92.33 \mathrm{ab}$ & $113.83 \mathrm{abc}$ & $104.83 \mathrm{ab}$ \\
\hline $\mathrm{B}$ & $10 \mathrm{t} / \mathrm{ha}$ & $63.93 \mathrm{ab}$ & $35.83 \mathrm{a}$ & $117.00 \mathrm{ab}$ & $110.33 \mathrm{ab}$ & $121.83 \mathrm{abc}$ & $161.75 \mathrm{ab}$ \\
\hline $\mathrm{A}$ & $20 \mathrm{t} / \mathrm{ha}$ & $32.08 \mathrm{~b}$ & $27.67 \mathrm{a}$ & $86.08 \mathrm{~b}$ & $83.67 \mathrm{~b}$ & $99.00 \mathrm{bc}$ & $103.75 \mathrm{ab}$ \\
\hline $\mathrm{B}$ & $20 \mathrm{t} / \mathrm{ha}$ & $48.67 \mathrm{ab}$ & $33.08 \mathrm{a}$ & $82.08 \mathrm{~b}$ & $93.33 \mathrm{ab}$ & $95.75 \mathrm{c}$ & $82.08 \mathrm{~b}$ \\
\hline $\mathrm{A}$ & $30 \mathrm{kgN} / \mathrm{ha}$ & $101.17 \mathrm{a}$ & $30.25 \mathrm{a}$ & $144.33 \mathrm{a}$ & $148.43 \mathrm{a}$ & $167.08 \mathrm{a}$ & $141.17 \mathrm{a}$ \\
\hline $\mathrm{B}$ & $30 \mathrm{kgN} / \mathrm{ha}$ & $36.50 \mathrm{~b}$ & $28.67 \mathrm{a}$ & $122.67 \mathrm{ab}$ & $130.33 \mathrm{ab}$ & $133.92 \mathrm{abc}$ & $122.58 \mathrm{ab}$ \\
\hline
\end{tabular}




\begin{tabular}{|c|c|c|c|c|c|c|c|}
\hline A & $60 \mathrm{kgN} / \mathrm{ha}$ & $64.58 \mathrm{ab}$ & $25.50 \mathrm{a}$ & $107.33 \mathrm{ab}$ & $121.50 \mathrm{ab}$ & $130.33 \mathrm{abc}$ & $106.58 \mathrm{ab}$ \\
\hline B & $60 \mathrm{kgN} / \mathrm{ha}$ & $19.83 \mathrm{~b}$ & $27.50 \mathrm{a}$ & $125.58 \mathrm{ab}$ & $109.50 \mathrm{ab}$ & $155.33 \mathrm{ab}$ & $128.75 \mathrm{ab}$ \\
\hline S. E & & 19.21 & 3.2 & 16.2 & 20.11 & 17.57 & 15.55 \\
\hline
\end{tabular}

$\mathrm{A}=$ White variety, $\mathrm{B}=$ Black variety, values with different letters along the columns are significantly different using DMRT at $5 \%$ probability level. Wk $=$ weeks after planting.

Table 5: Effect of variety and fertilizer application on Bambara nut number of nodes at different growth stages.

\begin{tabular}{|c|c|c|c|c|c|c|c|}
\hline Variety & Fert. Rates & $\mathbf{2 w k}$ & $\mathbf{4 w k}$ & $\mathbf{6 w k}$ & $\mathbf{8 w k}$ & $\mathbf{1 0 w k}$ & $\mathbf{1 2} \mathbf{w k}$ \\
\hline $\mathrm{A}$ & $0 \mathrm{kgN} / \mathrm{ha}$ & $117.12 \mathrm{ab}$ & $29.25 \mathrm{ab}$ & $129.2 \mathrm{a}$ & $127.17 \mathrm{a}$ & $137.25 \mathrm{a}$ & $137.25 \mathrm{a}$ \\
\hline B & $0 \mathrm{kgN} / \mathrm{ha}$ & $20.89 \mathrm{ab}$ & $32.58 \mathrm{ab}$ & $116.4 \mathrm{a}$ & $98.17 \mathrm{a}$ & $122.08 \mathrm{a}$ & $124.17 \mathrm{a}$ \\
\hline $\mathrm{A}$ & $10 \mathrm{t} / \mathrm{ha}$ & $10.25 \mathrm{~b}$ & $37.42 \mathrm{ab}$ & $113.0 \mathrm{a}$ & $95.33 \mathrm{a}$ & $116.00 \mathrm{a}$ & $115.67 \mathrm{a}$ \\
\hline B & $10 \mathrm{t} / \mathrm{ha}$ & $22.70 \mathrm{ab}$ & $39.42 \mathrm{a}$ & $126.5 \mathrm{a}$ & $117.42 \mathrm{a}$ & $129.17 \mathrm{a}$ & $123.50 \mathrm{a}$ \\
\hline A & $20 \mathrm{t} / \mathrm{ha}$ & $9.90 \mathrm{~b}$ & $28.25 \mathrm{~b}$ & $107.1 \mathrm{a}$ & $90.00 \mathrm{a}$ & $107.17 \mathrm{a}$ & $101.25 \mathrm{a}$ \\
\hline B & $20 \mathrm{t} / \mathrm{ha}$ & $14.98 \mathrm{ab}$ & $34.42 \mathrm{ab}$ & $108.2 \mathrm{a}$ & $92.67 \mathrm{a}$ & $98.67 \mathrm{a}$ & $104.00 \mathrm{a}$ \\
\hline A & $30 \mathrm{kgN} / \mathrm{ha}$ & $28.41 \mathrm{a}$ & $32.00 \mathrm{ab}$ & $152.4 \mathrm{a}$ & $143.75 \mathrm{a}$ & $152.67 \mathrm{a}$ & $104.00 \mathrm{a}$ \\
\hline B & $30 \mathrm{kgN} / \mathrm{ha}$ & $12.55 \mathrm{ab}$ & $29.17 \mathrm{ab}$ & $138.9 \mathrm{a}$ & $127.58 \mathrm{a}$ & $134.17 \mathrm{a}$ & $136.33 \mathrm{a}$ \\
\hline A & $60 \mathrm{kgN} / \mathrm{ha}$ & $16.25 \mathrm{ab}$ & $28.08 \mathrm{~b}$ & $129.0 \mathrm{a}$ & $113.83 \mathrm{a}$ & $118.83 \mathrm{a}$ & $130.58 \mathrm{a}$ \\
\hline B & $60 \mathrm{kgN} / \mathrm{ha}$ & $5.94 \mathrm{~b}$ & $27.00 \mathrm{~b}$ & $137.7 \mathrm{a}$ & $128.67 \mathrm{a}$ & $130.08 \mathrm{a}$ & $136.00 \mathrm{a}$ \\
\hline S. E & & 5.55 & 3.27 & 17.36 & 19.46 & 16.75 & 16.18 \\
\hline
\end{tabular}

$\mathrm{A}=$ White variety, $\mathrm{B}=$ Black variety, values with different letters along the columns are significantly different using DMRT at $5 \%$ probability level. Wk $=$ weeks after planting.

Table 6: Effect of variety and fertilizer application on Bambara nut plant height at different growth stages.

\begin{tabular}{|c|c|c|c|c|c|c|c|}
\hline Variety & Fert. rates & $\mathbf{2 w k}$ & $\mathbf{4 w k}$ & $\mathbf{6 w k}$ & $\mathbf{8 w k}$ & $\mathbf{1 0 w k}$ & $\mathbf{1 2 w k}$ \\
\hline $\mathrm{A}$ & $0 \mathrm{kgN} / \mathrm{ha}$ & $10.69 \mathrm{a}$ & $18.17 \mathrm{ab}$ & $23.92 \mathrm{ab}$ & $26.25 \mathrm{a}$ & $22.75 \mathrm{a}$ & $23.92 \mathrm{abc}$ \\
\hline $\mathrm{B}$ & $0 \mathrm{kgN} / \mathrm{ha}$ & $10.47 \mathrm{a}$ & $17.50 \mathrm{ab}$ & $18.83 \mathrm{c}$ & $24.08 \mathrm{a}$ & $23.50 \mathrm{a}$ & $19.67 \mathrm{~d}$ \\
\hline $\mathrm{A}$ & $10 \mathrm{t} / \mathrm{ha}$ & $3.45 \mathrm{a}$ & $17.92 \mathrm{ab}$ & $24.83 \mathrm{ab}$ & $24.83 \mathrm{a}$ & $23.92 \mathrm{a}$ & $24.83 \mathrm{abc}$ \\
\hline $\mathrm{B}$ & $10 \mathrm{t} / \mathrm{ha}$ & $17.16 \mathrm{a}$ & $17.25 \mathrm{ab}$ & $23.83 \mathrm{ab}$ & $24.92 \mathrm{a}$ & $24.25 \mathrm{a}$ & $21.25 \mathrm{~cd}$ \\
\hline $\mathrm{A}$ & $20 \mathrm{t} / \mathrm{ha}$ & $8.29 \mathrm{a}$ & $17.00 \mathrm{ab}$ & $21.83 \mathrm{bc}$ & $22.00 \mathrm{a}$ & $23.58 \mathrm{a}$ & $21.83 \mathrm{bcd}$ \\
\hline $\mathrm{B}$ & $20 \mathrm{t} / \mathrm{ha}$ & $5.76 \mathrm{a}$ & $17.25 \mathrm{ab}$ & $22.17 \mathrm{bc}$ & $23.08 \mathrm{a}$ & $22.67 \mathrm{a}$ & $24.25 \mathrm{abc}$ \\
\hline $\mathrm{A}$ & $30 \mathrm{kgN} / \mathrm{ha}$ & $11.82 \mathrm{a}$ & $16.58 \mathrm{~b}$ & $27.58 \mathrm{a}$ & $24.17 \mathrm{a}$ & $26.08 \mathrm{a}$ & $27.75 \mathrm{a}$ \\
\hline $\mathrm{B}$ & $30 \mathrm{kgN} / \mathrm{ha}$ & $4.89 \mathrm{a}$ & $17.67 \mathrm{ab}$ & $24.83 \mathrm{ab}$ & $23.67 \mathrm{a}$ & $22.67 \mathrm{a}$ & $25.67 \mathrm{ab}$ \\
\hline $\mathrm{A}$ & $60 \mathrm{kgN} / \mathrm{ha}$ & $4.00 \mathrm{a}$ & $17.00 \mathrm{ab}$ & $25.75 \mathrm{ab}$ & $25.67 \mathrm{a}$ & $26.17 \mathrm{a}$ & $26.08 \mathrm{a}$ \\
\hline B & $60 \mathrm{kgN} / \mathrm{ha}$ & $6.60 \mathrm{a}$ & $21.00 \mathrm{a}$ & $25.17 \mathrm{ab}$ & $25.92 \mathrm{a}$ & $26.17 \mathrm{a}$ & $26.25 \mathrm{a}$ \\
\hline S. E & & 4.84 & 1.35 & 1.25 & 1.6 & 2.34 & 1.24 \\
\hline
\end{tabular}

$\mathrm{A}=$ White variety, $\mathrm{B}=$ Black variety, values with different letters along the columns are significantly different using DMRT at $5 \%$ probability level. Wk $=$ week after planting.

Table 7: Effect of variety and fertilizer application on Bambara nut number of branches at different growth stages.

\begin{tabular}{|c|c|c|c|c|c|c|c|}
\hline Variety & Fert. Rates & $\mathbf{2 w k}$ & $\mathbf{4 w k}$ & $\mathbf{6 w k}$ & $\mathbf{8 w k}$ & $\mathbf{1 0 w k}$ & $\mathbf{1 2 w k}$ \\
\hline $\mathrm{A}$ & $0 \mathrm{kgN} / \mathrm{ha}$ & $9.37 \mathrm{ab}$ & $6.42 \mathrm{~b}$ & $9.67 \mathrm{~b}$ & $12.42 \mathrm{ab}$ & $13.25 \mathrm{ab}$ & $10.25 \mathrm{a}$ \\
\hline $\mathrm{B}$ & $0 \mathrm{kgN} / \mathrm{ha}$ & $11.95 \mathrm{ab}$ & $7.25 \mathrm{ab}$ & $10.75 \mathrm{~b}$ & $10.33 \mathrm{ab}$ & $9.75 \mathrm{~b}$ & $10.58 \mathrm{a}$ \\
\hline $\mathrm{A}$ & $10 \mathrm{t} / \mathrm{ha}$ & $5.53 \mathrm{ab}$ & $7.33 \mathrm{ab}$ & $13.42 \mathrm{ab}$ & $9.50 \mathrm{~b}$ & $13.17 \mathrm{ab}$ & $13.25 \mathrm{a}$ \\
\hline $\mathrm{B}$ & $10 \mathrm{t} / \mathrm{ha}$ & $8.7 \mathrm{a}$ & $9.08 \mathrm{a}$ & $10.33 \mathrm{~b}$ & $11.50 \mathrm{ab}$ & $11.33 \mathrm{ab}$ & $11.83 \mathrm{a}$ \\
\hline $\mathrm{A}$ & $20 \mathrm{t} / \mathrm{ha}$ & $4.61 \mathrm{~b}$ & $6.67 \mathrm{~b}$ & $13.58 \mathrm{ab}$ & $11.42 \mathrm{ab}$ & $13.58 \mathrm{ab}$ & $13.58 \mathrm{a}$ \\
\hline $\mathrm{B}$ & $20 \mathrm{t} / \mathrm{ha}$ & $7.39 \mathrm{ab}$ & $7.58 \mathrm{ab}$ & $10.75 \mathrm{~b}$ & $16.08 \mathrm{a}$ & $10.25 \mathrm{ab}$ & $18.58 \mathrm{a}$ \\
\hline $\mathrm{A}$ & $30 \mathrm{kgN} / \mathrm{ha}$ & $17.70 \mathrm{a}$ & $6.50 \mathrm{~b}$ & $9.67 \mathrm{~b}$ & $14.92 \mathrm{ab}$ & $9.75 \mathrm{~b}$ & $9.75 \mathrm{a}$ \\
\hline $\mathrm{B}$ & $30 \mathrm{kgN} / \mathrm{ha}$ & $7.41 \mathrm{ab}$ & $7.02 \mathrm{ab}$ & $11.58 \mathrm{~b}$ & $9.08 \mathrm{~b}$ & $14.08 \mathrm{ab}$ & $14.33 \mathrm{a}$ \\
\hline $\mathrm{A}$ & $60 \mathrm{kgN} / \mathrm{ha}$ & $11.91 \mathrm{ab}$ & $6.92 \mathrm{~b}$ & $13.42 \mathrm{ab}$ & $9.08 \mathrm{~b}$ & $14.08 \mathrm{ab}$ & $14.33 \mathrm{a}$ \\
\hline B & $60 \mathrm{kgN} / \mathrm{ha}$ & $3.25 \mathrm{~b}$ & $6.42 \mathrm{~b}$ & $17.50 \mathrm{a}$ & $10.50 \mathrm{ab}$ & $15.17 \mathrm{a}$ & $17.25 \mathrm{a}$ \\
\hline S. E & & 3.9 & 0.66 & 1.81 & 2 & 1.62 & 4.16 \\
\hline
\end{tabular}

$A=$ White variety, $B=$ Black variety, values with different letters along the columns are significantly different using DMRT at $5 \%$ probability level. Wk $=$ week after planting. 
Table 8:Effect of variety and fertilizer application on Bambara nut number of flowers at different growth stages.

\begin{tabular}{|c|c|c|c|c|c|}
\hline Variety & Fert. Rates & $6 w k$ & $8 w k$ & $10 w k$ & $12 \mathrm{wk}$ \\
\hline A & $0 \mathrm{kgN} / \mathrm{ha}$ & $0.33 \mathrm{a}$ & $7.83 \mathrm{a}$ & $1.00 \mathrm{a}$ & $0.33 \mathrm{~b}$ \\
\hline B & $0 \mathrm{kgN} / \mathrm{ha}$ & $0.42 \mathrm{a}$ & $3.42 \mathrm{a}$ & $1.25 \mathrm{a}$ & $0.08 \mathrm{~b}$ \\
\hline A & 10t/ha & $1.00 \mathrm{a}$ & $6.83 \mathrm{a}$ & $1.58 \mathrm{a}$ & $1.00 \mathrm{ab}$ \\
\hline B & 10t/ha & $0.50 \mathrm{a}$ & $4.75 \mathrm{a}$ & $0.75 \mathrm{a}$ & $0.58 \mathrm{ab}$ \\
\hline A & $20 \mathrm{t} / \mathrm{ha}$ & $0.67 \mathrm{a}$ & $6.25 \mathrm{a}$ & $1.08 \mathrm{a}$ & $0.67 \mathrm{ab}$ \\
\hline B & 20t/ha & $0.83 \mathrm{a}$ & $4.17 \mathrm{a}$ & $1.08 \mathrm{a}$ & $0.67 \mathrm{ab}$ \\
\hline A & $30 \mathrm{kgN} / \mathrm{ha}$ & $0.50 \mathrm{a}$ & $7.33 \mathrm{a}$ & $0.50 \mathrm{a}$ & $0.33 \mathrm{~b}$ \\
\hline B & $30 \mathrm{kgN} / \mathrm{ha}$ & $0.83 \mathrm{a}$ & $5.83 \mathrm{a}$ & $0.83 \mathrm{a}$ & $0.92 \mathrm{ab}$ \\
\hline A & $60 \mathrm{kgN} / \mathrm{ha}$ & $1.67 \mathrm{a}$ & $3.33 \mathrm{a}$ & $0.75 \mathrm{a}$ & $2.17 \mathrm{a}$ \\
\hline B & $60 \mathrm{kgN} / \mathrm{ha}$ & $0.75 \mathrm{a}$ & $7.67 \mathrm{a}$ & $1.50 \mathrm{a}$ & $0.83 \mathrm{ab}$ \\
\hline S.E & & 0.54 & 2.22 & 0.62 & 0.55 \\
\hline
\end{tabular}

$A=$ White variety, $B=$ Black variety, values with different letters along the columns are significantly different using DMRT at $5 \%$ probability level. Wk = week after planting.

Table 9: Effect of variety on the Bambara nut seed yield parameters.

\begin{tabular}{|c|c|c|c|c|c|c|c|}
\hline Variety & Weight of Pods & Number of Pods & Weight of Shaft & $\begin{array}{c}\text { Weight of } \\
\text { Seeds }\end{array}$ & $\begin{array}{c}\text { Number of } \\
\text { Seeds }\end{array}$ & $\begin{array}{c}\text { Number of Bad } \\
\text { Seeds }\end{array}$ & $\begin{array}{c}\text { Weight of Bad } \\
\text { Seeds }\end{array}$ \\
\hline A & $339.86 \mathrm{a}$ & $66.75 \mathrm{a}$ & $21.54 \mathrm{a}$ & $54.77 \mathrm{a}$ & $68.30 \mathrm{a}$ & $6.40 \mathrm{a}$ & $4.38 \mathrm{a}$ \\
\hline B & $196.15 \mathrm{a}$ & $63.22 \mathrm{a}$ & $24.27 \mathrm{a}$ & $53.09 \mathrm{a}$ & $72.32 \mathrm{a}$ & $6.82 \mathrm{a}$ & $2.70 \mathrm{a}$ \\
\hline S. E & 255.79 & 5.49 & 2.34 & 4.85 & 5.37 & 1.02 & 0.86 \\
\hline
\end{tabular}

$A=$ White variety, $B=$ Black variety, values with different letters along the columns are significantly different using DMRT at $5 \%$ probability level.

Table 10: Effects of fertilizer application on Bambara nut seed yield parameters.

\begin{tabular}{|c|c|c|c|c|c|c|c|}
\hline Fertilizer & Weight of Pods & $\begin{array}{c}\text { Number of } \\
\text { Pods }\end{array}$ & Weight of Shaft & Weight of Seeds & $\begin{array}{c}\text { Number of } \\
\text { Seeds }\end{array}$ & $\begin{array}{c}\text { Number of Bad } \\
\text { Seeds }\end{array}$ & $\begin{array}{c}\text { Weight of Bad } \\
\text { Seeds }\end{array}$ \\
\hline $0 \mathrm{~kg}$ & $59.13 \mathrm{a}$ & $61.95 \mathrm{a}$ & $24.17 \mathrm{a}$ & $50.94 \mathrm{a}$ & $60.04 \mathrm{a}$ & $7.04 \mathrm{a}$ & $4.3 \mathrm{a}$ \\
\hline $10 \mathrm{t} / \mathrm{ha}$ & $70.96 \mathrm{a}$ & $84.75 \mathrm{a}$ & $22.54 \mathrm{a}$ & $53.97 \mathrm{a}$ & $83.33 \mathrm{a}$ & $8.84 \mathrm{a}$ & $4.0 \mathrm{a}$ \\
\hline $20 \mathrm{t} / \mathrm{ha}$ & $63.75 \mathrm{a}$ & $70.92 \mathrm{a}$ & $20.83 \mathrm{a}$ & $53.65 \mathrm{a}$ & $70.71 \mathrm{a}$ & $8.46 \mathrm{a}$ & $4.0 \mathrm{a}$ \\
\hline $30 \mathrm{kgN} / \mathrm{ha}$ & $68.83 \mathrm{a}$ & $80.48 \mathrm{a}$ & $23.67 \mathrm{a}$ & $54.66 \mathrm{a}$ & $71.04 \mathrm{a}$ & $8.42 \mathrm{a}$ & $3.5 \mathrm{a}$ \\
\hline $60 \mathrm{kgN} / \mathrm{ha}$ & $62.25 \mathrm{a}$ & $84.36 \mathrm{a}$ & $23.32 \mathrm{a}$ & $56.42 \mathrm{a}$ & $66.42 \mathrm{a}$ & $5.29 \mathrm{a}$ & $1.7 \mathrm{a}$ \\
\hline S. E & 8.68 & 9.44 & 3.7 & 7.66 & 8.49 & 1.63 & 1.36 \\
\hline
\end{tabular}

$\mathrm{A}=$ White variety, $\mathrm{B}=$ Black variety, values with different letters along the columns are significantly different using DMRT at $5 \%$ probability level.

Table 11: Effect of variety and fertilizer application on Bambara nut seed yield parameters.

\begin{tabular}{|c|c|c|c|c|c|c|c|c|}
\hline Variety & Fertilizer & Weight of Pods & Number of Pods & $\begin{array}{c}\text { Weight of } \\
\text { Shaft }\end{array}$ & $\begin{array}{c}\text { Weight of } \\
\text { Seeds }\end{array}$ & $\begin{array}{c}\text { Number of } \\
\text { Seeds }\end{array}$ & $\begin{array}{c}\text { Number of } \\
\text { Bad Seeds }\end{array}$ & $\begin{array}{c}\text { Weight of Bad } \\
\text { Seeds }\end{array}$ \\
\hline $\mathrm{A}$ & $0 \mathrm{kgN} / \mathrm{ha}$ & $93.90 \mathrm{a}$ & $46.18 \mathrm{a}$ & $32.48 \mathrm{a}$ & $40.08 \mathrm{a}$ & $73.8 \mathrm{a}$ & $9.42 \mathrm{a}$ & $6.49 \mathrm{a}$ \\
\hline $\mathrm{B}$ & $0 \mathrm{kgN} / \mathrm{ha}$ & $45.20 \mathrm{a}$ & $42.08 \mathrm{a}$ & $15.85 \mathrm{ab}$ & $31.80 \mathrm{~b}$ & $46.2 \mathrm{a}$ & $4.67 \mathrm{a}$ & $2.25 \mathrm{a}$ \\
\hline $\mathrm{A}$ & $10 \mathrm{t} / \mathrm{ha}$ & $88.10 \mathrm{a}$ & $69.92 \mathrm{a}$ & $18.81 \mathrm{ab}$ & $48.21 \mathrm{ab}$ & $83.0 \mathrm{a}$ & $9.35 \mathrm{a}$ & $3.26 \mathrm{a}$ \\
\hline $\mathrm{B}$ & $10 \mathrm{t} / \mathrm{ha}$ & $81.40 \mathrm{a}$ & $72.00 \mathrm{a}$ & $26.26 \mathrm{ab}$ & $59.73 \mathrm{ab}$ & $83.6 \mathrm{a}$ & $8.33 \mathrm{a}$ & $4.87 \mathrm{a}$ \\
\hline $\mathrm{A}$ & $20 \mathrm{tt} / \mathrm{ha}$ & $62.70 \mathrm{a}$ & $66.58 \mathrm{a}$ & $19.75 \mathrm{ab}$ & $52.94 \mathrm{ab}$ & $64.9 \mathrm{a}$ & $10.92 \mathrm{a}$ & $5.90 \mathrm{a}$ \\
\hline $\mathrm{B}$ & $20 \mathrm{t} / \mathrm{ha}$ & $79.10 \mathrm{a}$ & $60.92 \mathrm{a}$ & $21.92 \mathrm{ab}$ & $54.37 \mathrm{ab}$ & $76.5 \mathrm{a}$ & $6.00 \mathrm{a}$ & $2.04 \mathrm{a}$ \\
\hline $\mathrm{A}$ & $30 \mathrm{kgN} / \mathrm{ha}$ & $81.70 \mathrm{a}$ & $67.92 \mathrm{a}$ & $22.30 \mathrm{ab}$ & $54.32 \mathrm{ab}$ & $67.0 \mathrm{a}$ & $8.67 \mathrm{a}$ & $4.76 \mathrm{a}$ \\
\hline $\mathrm{B}$ & $30 \mathrm{kgN} / \mathrm{ha}$ & $79.30 \mathrm{a}$ & $69.75 \mathrm{a}$ & $25.05 \mathrm{ab}$ & $55.01 \mathrm{ab}$ & $75.0 \mathrm{a}$ & $8.17 \mathrm{a}$ & $2.32 \mathrm{a}$ \\
\hline $\mathrm{A}$ & $60 \mathrm{kgN} / \mathrm{ha}$ & $73.00 \mathrm{a}$ & $53.17 \mathrm{a}$ & $14.36 \mathrm{~b}$ & $48.28 \mathrm{ab}$ & $52.6 \mathrm{a}$ & $3.67 \mathrm{a}$ & $1.50 \mathrm{a}$ \\
\hline B & $60 \mathrm{kgN} / \mathrm{ha}$ & $95.70 \mathrm{a}$ & $71.33 \mathrm{a}$ & $32.28 \mathrm{a}$ & $64.56 \mathrm{ab}$ & $80.1 \mathrm{a}$ & $6.92 \mathrm{a}$ & $2.02 \mathrm{a}$ \\
\hline S. E & & 17.96 & 12.27 & 5.23 & 10.83 & 12 & 2.33 & 1.93 \\
\hline
\end{tabular}

$A=$ White variety, $B=$ Black variety, values with different letters along the columns are significantly different using DMRT at $5 \%$ probability level. No. $=$ numbers.

\section{Discussion}

The varietal effect on the Bambara nut vegetative parameters where not significant in all growth stages except at 4WAP were number of branches on black varieties was significant and, at 6 and 12WAP, plant height was the white variety produced a significant taller plant more than the black variety. These indicate that the 
white variety had the potential for better competition for capturing and utilization of solar radiation. The seed yield parameters of Bambara nut were not significant in the study, but white variety had higher mean value in most of the parameters measured when compared with the black variety. It is also observed that that at harvest the black variety had double seed mostly in their pods and the seeds are bigger in size mostly than the white variety which are mostly one seed per pod with a smaller seed.

The judicious use of fertilizer at recommended rate is very crucial in improving Bambara nut growth and seed yield parameters, as seen from the results obtained in the study.

It can be further stated that, application of inorganic fertilizer (urea) at 30 and $60 \mathrm{kgN} / \mathrm{ha}$, improve the vegetative growth parameter stage such as number of leaves, number of nodes, plant height and number of flowers at different growth stages of the plant that received urea at 30 and $60 \mathrm{KgN} /$ ha produced significant number of leaves, at 6 and 10 WAP as well as plant height at 6 and 10WAP. Furthermore, the application of $30 \mathrm{KgN} / \mathrm{ha}$ urea produced the best number of nodes, at 6, 8, 10, and 12WAP. This is in line with the work of [11], who reported that fertilizers, especially those containing higher nitrogen (like urea), leads to utilization of carbohydrates by crops, to form protoplasm and more cells, increase growth in consonant with increase in fertilizer rates. Ojo and Olufolaji [17] and Akanbi [18] added that when N is adequately supplied, it promotes cell division, accumulation of photosynthetic materials, leaf initiation and expansion. All these improve considerably plant growth and development. Application of poultry manure at the rate of $10 t /$ ha gives the highest average number of leaves, number of nodes, number of branches, at 4WAP and at all seed yield parameters taken in the study. This shows that application of 10t/ha poultry manure is adequate to produce Bambara nut. This is in line with the work of Hole et al, 2005 that poultry manure replenishes soil $\mathrm{N}$ and other elements and build up organic matter content of the soil that support crop yield and greater abundance of soil invertebrates and even reduced weed growth. Also, a positive effect of organic manure has been reported by Mc. Robic, [19] and Adediran et al, [20] to produce higher and better crop that keep longer and more nutritious than inorganic fertilizers. An improvement in the seed yield parameters in the study by poultry manure also agrees with the report of John et al, [21] that poultry manure contained essential nutrient elements that favors high photosynthetic activities to promote plant roots and vegetative growth. The combination of the white variety and $30 \mathrm{KgN} /$ ha urea produced better number of leaves, number of branches, and number of nodes in the study. This result indicated that white variety of Bambara nut has the potential to respond to fertilizer application through increased vegetative growth.

\section{Conclusion}

The study showed the response of two varieties of Bambara nut to organic and inorganic fertilizers with respect to most growth and yield parameters. The result of the experiment indicated that application of organic fertilizer as poultry manure at 10t/ha and inorganic fertilizer $(\mathrm{N})$ at $30 \mathrm{KgN} /$ ha (urea) are recommended for optimum yield production of Bambara nut.

\section{Acknowledgement}

None.

\section{Conflict of Interest}

No conflict of interest.

\section{References}

1. J Nyamangara, I Nyagumbo (2010) Interactive effects of selected nutrient resources and tied ridging on plant growth performance in a semi-arid smallholder farming environment in central Zimbabwe. Innovations as Key to the Green Revolution in Africa, pp. 357-363.

2. Tweneboah CK (2000) Modern Agriculture in the Tropics, Food crops. Co-wood Publishers.

3. Oliveira JS (1976) Grain legumes of Mozambique. Trop. Grain Legume Bull. 3: 13-15.

4. SH Brough, SN Azam Ali (1992) The effect of soil moisture on the proximate composition of bambara groundnut (Vigna subterranea (L) Verdc). J Sci Food Agric 60(2): 197-203.

5. EM Embaby, MM Abdel-Galil (2006) Seed born fungi and mycotoxins associated with some legume seeds in Egypt. Journal of Applied Sciences Research 2(11): 1064-1071.

6. Odendo M, Ojiem, J, Okwosa E (2004) Potential for Adoption of Legume Green Manure on Smallholder Farms in Western Kenya. In: Managing Nutrient Cycles to Sustain Soil Fertility in Sub-Saharan Africa, Bation, A (Ed) Academy Science Publishers, Nairobi, Kenya, pp. 557-570.

7. HF Perkins, (1964) Chiken Manure: Its Production, Composition and Use as a Fertilizer. Georgea Agricultural Experiment Stations. University of Georgea College of Agriculture, Dahlonega, USA, Pages: 123

8. SA Boateng, J Zickermann, M Kornahrens (2006) Poultry manure effect on growth and yield of maize. West Afr J Applied Ecol, 9: 1-11.

9. Harry H Schomberg, Dinku M Endale, Michael B Jenkins, Dwight S Fisher (2011) Nutrient source and tillage influences on nitrogen availability in a Southern Piedmonts corn cropping system. Biology and Fertility of Soils 47: 823-831.

10. Heldi M Waldrip, Zhongqi He, M Susan Erich (2011) Effects of poultry manure amendment on phosphorus uptake by ryegrass, soil phosphorus fractions and phosphates activity. Biology and Fertility of Soils 47(4): 407-418.

11. Chiezey UF, Yayock JY, Ahmed MK (1991) Effect of phosphorus and plant density on the yield components of soybean (Glycine max L, Merrill) Crop Science Research 4(1): 11-18.

12. Toungos DT, Sajo AA, Gungula DT (2010) Effect of $P_{205}$ on the yield and yield components of Bambara groundnut (vigna subterranean(L) Verdc) in Yola Adamawa State, Nigeria, World journal of fungal and plant biology 1(1): 1-7.

13. HE Shehu, Joshua D Kwari, MK Sandabe (2010) Effects of N, P, K fertilizers on yield, content and uptake of N, $\mathrm{P}$ and $\mathrm{K}$ by sesame (Sesamun indicum). International Journal of Agriculture and Biology 12(6): 845850.

14. Lloyd R Hossner, Anthony SR Juo (1999) Soil nutrient management for sustained food crop production in upland farming systems in the tropic. Food and fertilizer technology centre, Taiwan.

15. A.O.A.C. (1980) Official Methods of Analysis, $\left(13^{\text {th }}\right.$ edn) Association of official Analytical chemists, Washington D.C, Pp. 1038.

16. Kwanchai A Gomez, Arturo A Gomez (1984) Statistical procedures for agricultural research John Wiley and Sons, New York. Pp. 657.

17. 0jo and Olufolaji (1997) The performance of several morphotypes of amaranths current L. under two harvesting methods. Trop. Agric. (Trinidad) 66: 273-276.

18. WB. Olabode OS. Olaniyi JO, Ojo AO (2004) Introduction to tropical crops. Raflink computer, Eleyele, Ibadan. Pp. 34-45. 
19. George McRobie (1998) Tools for organic farming, its manual of appropriate equipment and treatment. International technology publication. UK Pp. 77.

20. Adediran JA, Taiwo LB, Akande MO, Sobulo RA (1999) Comprehensive effect of organic based fertilizer and mineral on dry matter yield of maize. Boise research communication.

21. John L Havlin, Samuel L Werner L Nelson, James D Beaton (2004) Soil fertility and fertilizers: an introduction to nutrient management. Pearson education, India. Pp. 106-153.

22. Aliyu L Yusuf, Y, Ahmed, MK (1996) Response of pepper (capsicum annum L.) to fertilizer growth yield and yield components as affected by Nitrogen and Phosphorus levels. Paper presented at Horticultural Society of Nigeria conference $1^{\text {st }}-4^{\text {th }}$.
23. Amtmann A, Hammond JP, Armengaud P, White PJ (2006) Nutrient sensing and signaling in plants: Potassium and phosphorus. Adv. Botanical Res 43: 209-257.

24. Anita R Linnemann (1988) Cultivation of Bambara groundnut in northern Nigeria. Trop Crops Comm 15: 1-14.

25. Meirong Lv, Che Yuping, Zhongpei Li, Fengxiang X Han (2011) Soil organic, nutrients, microbial biomass and grain yield of rice (Orysa sativa L.) after 18 years of fertilizer application to an infertile paddy soil. Biology and Fertility of Soils 47(7): 777-783.

26. Okito A, Alves BJR, Urquiaga S, Boddey RM (2004) Isotopic fractionation during nitrogen fixation by four tropical legumes, Soil Biology and Chemistry 36(7): 1179-1190. 